\title{
AGRICULTURE
}

\section{CITRUS SCAB IN GEORGIA}

\author{
${ }^{1}$ Mziuri Gabaidze, $P h D$ in agrarian sciences \\ ${ }^{2}$ Guram Memarne, $P h D$ in agriculture \\ ${ }^{3}$ Neli Khalvashi
}

${ }^{1}$ Senior scientist, Department of Plant Diseases Monitoring, Diagnostics and Molecular Biology, Institute of Phytopathology and Biodiversity, Shota Rustaveli State University

${ }^{2}$ Chief scientist, Head of Institute of Phytopathology and Biodiversity, Shota Rustaveli State University

${ }^{3} \mathrm{PhD}$ in agrarian sciences, Chief scientist, Department of Biodiversity Monitoring and

Conservation, Institute of Phytopathology and Biodiversity, Batumi Shota Rustaveli State University

\section{DOI: https://doi.org/10.31435/rsglobal_ws/30082018/6052}

\section{ARTICLE INFO}

Received: 17 July 2018

Accepted: 18 August 2018

Published: 30 August 2018

\section{ABSTRACT}

Citrus yield is significantly reduced with the help of various pathogenic fungus. Elsinoe fawcetii Bitancourk De Jenk=Sphaceloma fawcetii Jenk differ by their nature of disseminating and harmfulness.

\section{KEYWORDS}

citrus,

fungus,

disease,

subtropical zone.

Citation: Mziuri Gabaidze, Guram Memarne, Neli Khalvashi. (2018) Citrus Scab in Georgia. World Science. 8(36), Vol.1. doi: 10.31435/rsglobal_ws/30082018/6052

Copyright: (c) 2018 Mziuri Gabaidze, Guram Memarne, Neli Khalvashi. This is an open-access article distributed under the terms of the Creative Commons Attribution License (CC BY). The use, distribution or reproduction in other forums is permitted, provided the original author(s) or licensor are credited and that the original publication in this journal is cited, in accordance with accepted academic practice. No use, distribution or reproduction is permitted which does not comply with these terms.

Introduction. Citrus culture is one of the main and leading areas in subtropical agriculture of Georgia. The spread of citrus fruits all over the world with the appropriate natural and climatic conditions can be explained by its pleasant taste, and also because citrus fruits contain a large amount of substances useful to the human body: carbohydrates, acids, acid organic salt, pectin substances and vitamins.

In addition, citrus cultures are highly profitable, and the costs of their cultivation are shortterm. In case of rational realization of agro technical measures, it is possible to grow 35-40 tons of high-quality fruit per 1 hectare.

Tangerine, orange and lemon have broad industrial value among citrus species in Georgia, which mainly are grown in the humid subtropical zone of the West Georgia. Although citrus production reached a high level in the 1980s, the development of this area has recently declined significantly. This was strongly influenced by the social and economic situation in Georgia.

Diseases caused by various pathogenic microorganisms (fungus, bacterias, viruses) significantly reduce the productivity of citrus. They damage leaves, sprouts, fruits, flowers, knots, root neck and root systems (Snowden A. L. 1990), reduce yield, decrease commodity value and lead to the destruction of plants on a large scale during epiphytosis. Various adverse environmental factors also have a negative effect on citrus fruits (Mkervali V. G. 1987)

The following fungal diseases, which are spread in humid subtropical conditions of Western Georgia (Gikashvili K. G. 1984), are especially harmful: Malsecco (caused by Phoma tracheiphila (Petri) Kant. De Gik), Scab (caused by Elsinoe fawcetii Bitancourk De Jenk = Sphaceloma fawcetii Jenk.), Anthracnose or 
citrus black spot (caused by Clomerella cingulate (Stoneman) Spauld.H. shzenk $=$ Colletotrichum gloespozioides Penz.Sacc.), Melanose (caused by Diaporthe citri F.b. Wolf = Phomopsis citri H. Fawc.), Phytophthora (caused by Phytophthora citrophthora Leonia n., Phytophthora parasitica Dastur.), Alternaria, brown spot or ABS (caused by Alternaria citri Ellis et. N. Pierce.), Fuzarium (caused by Fuzarium oxysporum Schlecht., Fr. f. citri., Fuzarium javanicum Koord., Fuzarium sambucinum Fuck., f. citri., Fuzarium gibbosum App.et.Wz.) and etc (Beradze L. A., Kechakmadze L. A. 1984).

Research results. Citrus scab differs from the aforementioned fungal diseases by spreading and harmfulness in the subtropical zone of Georgia and is caused by fungus Elsinoe fawcetii Bitancourk. Sphaceloma favceti is characteristic of leaves, sprouts and fruits of mandarin, lemon, orange. The fungus also damages the leaves and sprouts of 1-2 year old plants. The spread of the disease is facilitated by wind, rain, spore carries insects (Dospechov B. 1979). The disease begins with those organs that were damaged in previous years. Warts are formed on damaged leaves which ore covered with cork material. First, the warts are yellowish, then turn into yellowish-brown and cover themselves with a velvet flakes. Damaged leaves are deformed, become curly and asymmetric. The same warts appear on the branches as on the leaves. Warts unite, form membrane after which the sprout is crooked and distorted. The surface of the damaged fruit is covered with purple-rusty warts. In case of severe disease, the fruit deforms, does not develop, falls and loses its commodity value. Fruit disease begins with the fruiting season. According to the scientific literature (Beradze L.A., Djakeli E. Sh., Motskobili N. A., Memarne G. R. 2008; Kanchaveli L. 1987), it is known that the spread of diseases reaches $18-28 \%$ under favorable conditions and 35-40\% - during epiphytosis.
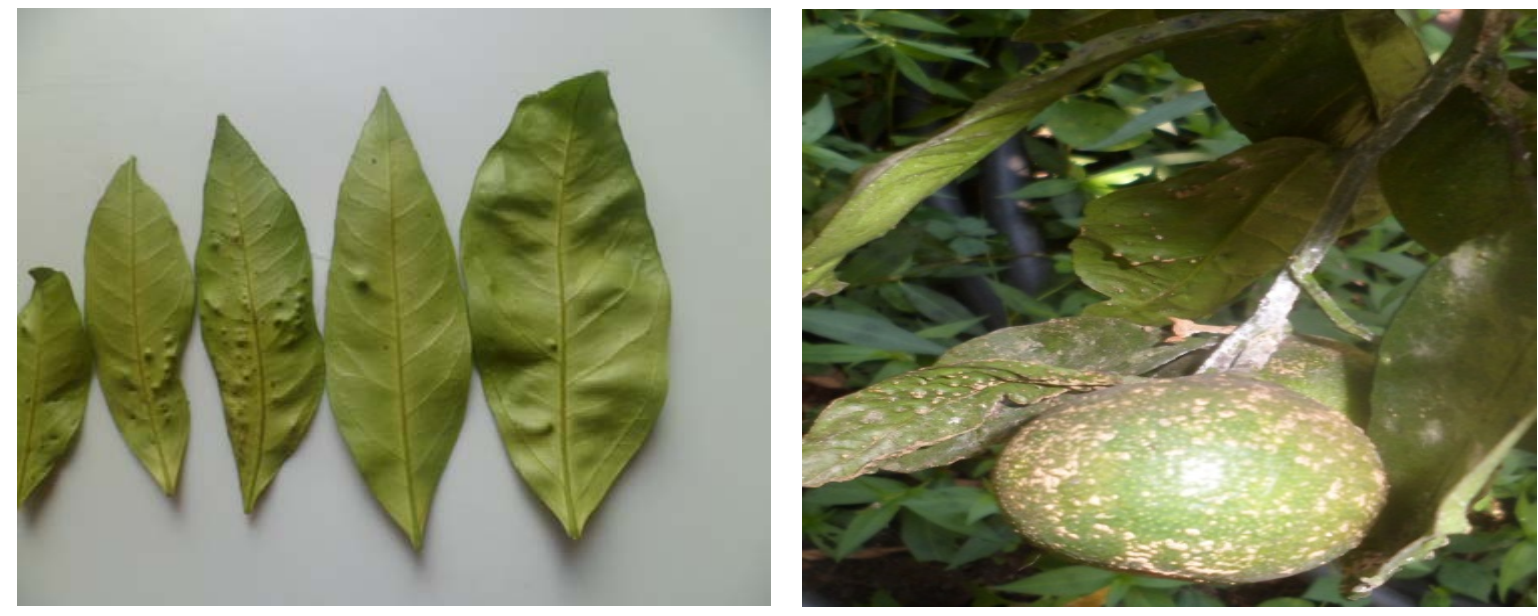

Fig. 1. Citrus scab symptoms on leaf and fruit

Monitoring of private plantations and demonstration plots in the municipalities of Chokhatauri, Ozurgeti, Kobuleti, Khelvachauri, Khobi, Zugdidi, Senaki was conducted to determine the spread of the disease. Monitoring was carried out at different stages of phonological development, in particular (flowering, fruiting, development and maturation of fruits, full maturation).

As a result of monitoring conducted in 2015-2017, scab was found in almost every species of citrus (mandarin, lemon, orange, grapefruit) which are spread in all the above-mentioned municipalities. Fungal warts were found on plant sprouts, leaves and fruits. Leaves and fruit are distorted. The spread of scab was also found in citrus trifoliate (Japanese orange). The focus of scab infection, but with less intensity, was found on mandarin and lemon plants in the test and demonstration nursery of the Agroservice Center of the Ministry of Agriculture of the Autonomous Republic of Adjara, which is located in Chakvi region.

It should be noted that the distribution of scab in the above-mentioned municipalities was much higher than it was known from the scientific literature.

The intensity of scab is very high also in those private farms and demonstration plots where monitoring was carried out.

According to the monitoring, the relatively low distribution and intensity of the scab was observed in the municipalities of Kobuleti and Khelvachauri and much higher in the Samegrelo region (Khobi, Zugdidi, Senaki). 


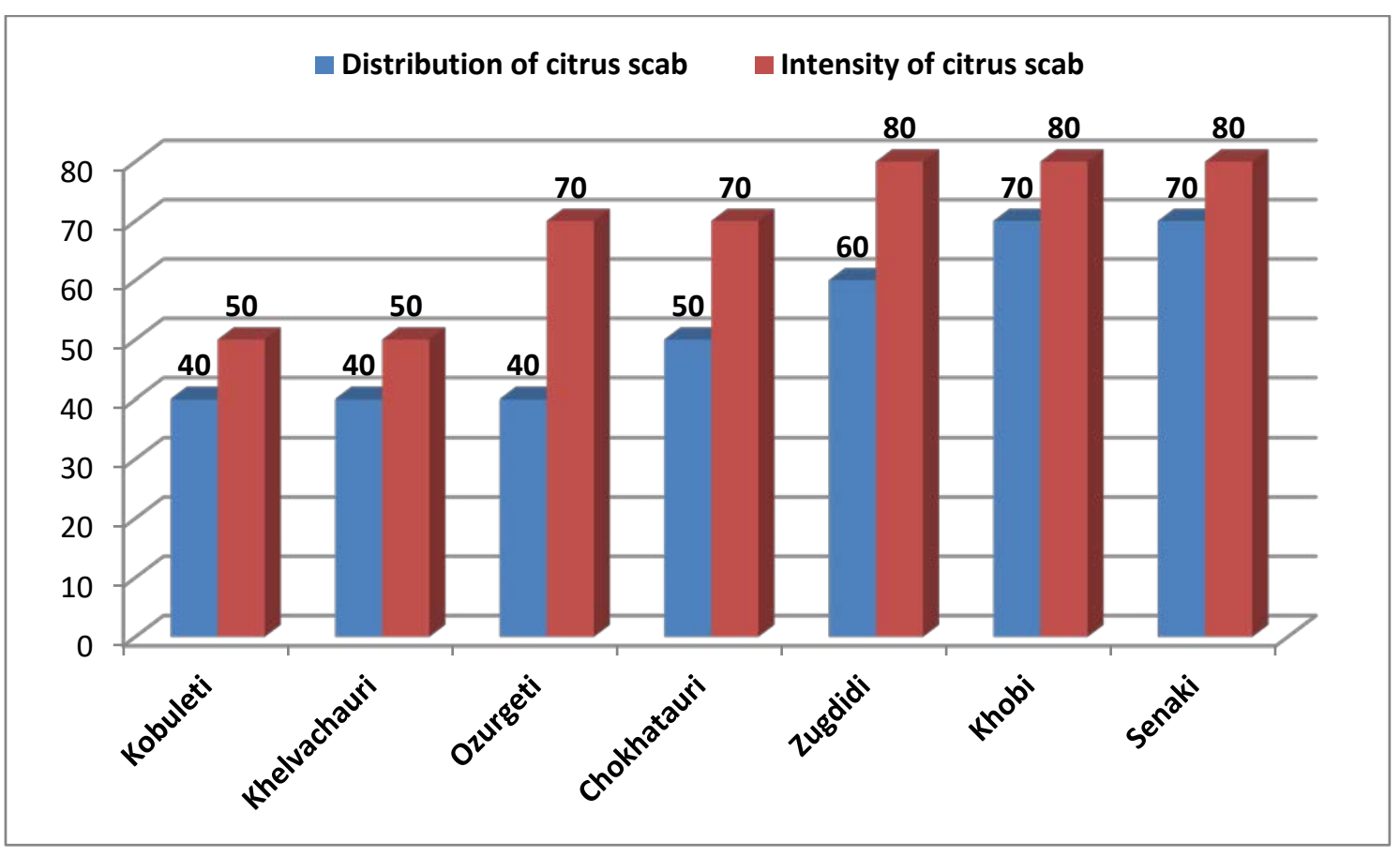

Fig. 2. Distribution and intensity of citrus scab in 2015-2017

Conclusion. Citrus scab is a very important disease due to its harmfulness and negative economic value. The disease was detected in every municipality of Western Georgia as a result of monitoring conducted in 2015-2017.

\section{REFERENCES}

1. Beradze L. A., Kechakmadze L. A. 1984. Major diseases of citrus fruits and fight against to him. Subtropical cultures N3, pp. -131-138);

2. Beradze L. A., Djakeli E. Sh., Motskobili N. A., Memarne G. R. 2008. Pathogenic fungi on citrus fruit in western Georgia. Abstracts book of first international Transcaucasus conference on plant pathology. P - 79;

3. Dospechov B. 1979. Methods of field experience. Kolos. Moscow;

4. Gikashvili K. G. 1984. Drying citrus plants in Georgia. Subtropical cultures N3, pp 126-131;

5. Kanchaveli L. 1987. Agricultural phytopathology. Tbilisi, pp. 143-149;

6. Mkervali V. G. 1987. Fungus disease of citrus crops and measures for restriction their harmfulness. Kiev pp. 1-98;

7. Snowden A. L. 1990. A Color Atlas of Post-Harvest Diseases and Disorders of Fruit and Vegetables. Volume 1. 